\title{
家庭内での二次感染を考慮したノロウイルス 感染症伝播モデルの構築
}

\author{
三浦 郁修 1 渡部 徹 2 ・渡辺 幸三 3 ・福士 謙介 4 \\ 1学生会員 東京大学学生 工学部都市工学科（†113-8656 東京都文京区本郷7-3-1） \\ E-mail:miurafuminari0815@gmail.com \\ 2正会員 山形大学准教授 農学部食料生命環境学科（†997-8555 山形県鶴岡市若葉町1-23） \\ E-mail:to-ru@tds1.tr.yamagata-u.ac.jp \\ 3 正会員 愛媛大学准教授 工学部環境建設工学科（干790-8577 愛媛県松山市文京町3番） \\ E-mail:watanabe_kozo@cee.ehime-u.ac.jp \\ 4正会員 東京大学教授 国際高等研究所サステイナビリティ学連携研究機構( テ113-8654 東京都文京区本 \\ 郷7-3-1) \\ E-mail:fukushi@ir3s.u-tokyo.ac.jp
}

\begin{abstract}
本研究では, 家庭内二次感染を考慮したノロウイルス感染症伝播モデルの構築, 対象地域でのモデルシ ミュレーションの実行, およびそのシミュレーション結果と疫学データの比較を通じた本モデルの有用性 を検討した. その結果, 流行のピークまでに要する時間は, 考察した4種類の不確定性が高いパラメーター のうち，NVを含む食品の摄取期間に敏感に反応することがわかった，加えて，家族構成に応じて，家庭内 二次感染リスクは一次感染リスクよりも大きくなることが定量的に示された. 特に, 総員 4 人以上で幼児が 存在寸る家庭では家庭内二次感染リスクは一次感染リスクの10倍以上になった. 最後に, 上記のパラメー ターに対するピーク時点の反応を利用し, 疫学データとの比較を通じた実際の流行に対するアプローチの 一例を示した。
\end{abstract}

Key Words : secondary infection, infectious disease, quantitative microbial risk assessment, infection model, Norovirus

\section{1. 序論}

世界保健機関(WHO)によると，下痢症が毎年 180 万人 の死亡要因となっている ${ }^{1)}$.このような感染症の問題は 発展途上国の夕ならず，日本を含む先進国でもいまだ残 る大きい課題として挙げられる2).

感染を大きく2つに区分すると, 河川水などの環境水や 食品等からの曝露により感染する一次感染と, ヒトが排 出した微生物に曝露することで感染する二次感染とに分 類できる，ノロウイルス(Norovirus; NV)は，その流行事 例から, 一次感染同様に二次感染についても重要な感染 形態であると考えられる. しかしながら下痢症の場合, 一次感染の曝露経路に対寸る定量的な評価 ${ }^{33,4)}$ は多くな されている一方で，二次感染の曝露経路に対する定量的 な評価はあまり行われていない, 二次感染では, 想定し うる感染経路が無限にあることや, 微量な病原微生物を 摂取することでも感染する可能性があり，その全てに対 して微生物の定量検出が困難であることが，その主たる
理由である.

そこで本研究では, 二次感染の生じる系として家庭に 注目し，家庭内二次感染についてのモデル構築，および 感染流行シミュレーションの実行を目的とした。具体的 には，定量的微生物リスク評価手法 ${ }^{5}$ (Quantitative Microbial Risk Assessment: QMRA)を用いることで, モデル構築 を行った. QMRAを用いることの利点として, 感染経路 を明確に追跡したモデルを構築できることが挙げられる. すなわち，様々な微生物移動に対する対応策の効果を評 価することが可能になる.

モデル構築およびシミュレーションの実行は以下のよ うに行った。第一に家庭内二次感染を考慮に入れた下痢 症の家庭内伝播モデルを構築した，続いて，その家庭内 伝播モデルを対象地域(モデル地域)の全世帯に実行し, それを地域内の感染流行シミュレーションとした. ここ から, 家庭内二次感染が地域内の感染流行にどの程度影 響を与えているか評価を行った，さらに，構築したモデ ルで予測される流行と同地域の疫学データ(実際の患者 
報告数)とを比較することで，モデルの有用性を検討した. なお, 本研究では, 構築したモデルを用いて, 現時点 で入手可能なデータにもとづくシミュレーション例を示 すことを目的としており，曝露シナリオや感染者の行動 等に関しては一部で不確実な設定を行っている.よって, 本研究の結果が現実の感染流行をそのまま表していない ことに注意願いたい.

\section{2. 方法}

\section{(1) 家庭内伝播モデルの構築方法}

\section{a) 構築方法の概要}

本研究では，粪便中の病原微生物が手と手の接触によ りヒトからヒトへ移動し, 感染拡大が生じる現象の再現 を意図してモデル構築を行った，家庭を境界（つまり， 家庭外での手と手の接触は考えない）として，境界外部 となる環境中から摂取した病原微生物による感染を一次 感染, 家庭に所属する人の糞便由来の病原微生物による 感染を家庭内二次感染と定義した. ここでいう“家庭” とは, 人々が共生している1つの住居を指している. 家庭 内二次感染では, 感染者の嘔吐も主要な感染源となるが, 本研究では糞口経路での二次感染のみに着目して解析を 行う.

\section{b) 家庭内構成員の定義}

1つの住居を構成している構成員のうち“父”“母”“子” “幼児”の4属性に区分した. この属性区分に該当しない 人員(例えば祖父母や同居している親類等)についてはモ デルから除外した.ここで，幼児はおむつをしている乳 幼児(3歳未満), 子はおむむつとれた児童・青年(3歳以上 18歳未満)として定義した.

\section{c) 属性毎の感染判定方法}

前項で述べた属性毎に, 1日単位で感染判定を行った. まず, 次節で設定を行なう感染経路と曝露量算出方法に 基づき, 1日あたりの病原微生物への曝露量を算出した. その曝露量からdose-response式に基づき感染確率(リス ク)を算出し, そのリスクと発生させた乱数と比較するこ とによって感染判定を行った（すなわち，モンテカルロ シミュレーションを実行した）。これを属性毎に1日単位 で行い，それをシミュレーション期間(365日)だけ繰り返 し行った. 1日あたりの感染者数をカウントする際には, 発症した初日にのみ1人とカウントし，2日目以降は感染 者数としてカウントしないものとした. 加えて, シミュ レーション開始の日付を2012年11月1日とし,このときの 感染者数は地域内の全家庭において0とした.

本モデルにおいては, 前日の構成員の感染状態に応じ て, 逐次的に粪便由来の曝露量が変遷していき, さらに その曝露量に応じて次の感染判定が実行される.この365 日分のシミュレーションを1回として，1万回繰り返しを
行なうことで精度を向上させた.

また，シミュレーションはR言語を用いて実行した。

\section{d) 感染者の病状等に関する仮定}

感染者は，その感染の有無に関わらず，健常状態と同 様の行動を継続してとるものとした．よって，二次感染 に関わる諸々のパラメーター (NVを含む粪便の排出期間 や糞便中のNV濃度など）については, すべての感染者で 同一とした. ここから，本シミュレーションでは感染者 と発症者は同一のものとみなした.

また，感染している状態で重複して感染することはな く, NVには多様な遺伝子型が存在することが知られてい るため, 一度感染しても他の遺伝子型のウイルスに感染 する可能性を考慮して, 期間中に2回以上感染し得るもの と設定した，重複して感染しないことから，自分の糞便 からは感染し得ないものとした。 なお，表-2中に示す dose-response式は血液型抗原の分泌型 $(\mathrm{Se}+)$ を対象にし ているが，対象地域の住民のうちこの型の割合が不明な ため, シミュレーションにおいては対象地域の全住民を 分必型と仮定している.

NVを含む粪便の排出期間や病状継続期間は表-2にま とめてある.ここで述べた通り, 病状継続期間・免疫の 獲得・不顕性確率は考慮していない.

\section{(2) 地域内での感染流行シミュレーション}

前述した家庭内伝播モデルのシミュレーションを地域 内の世帯数分行うことで地域内の感染者数・感染流行の シミュレーションとした.このとき, 各家庭内に存在す る各属性の人員数と家庭内に存在する人員数に応じて異 なるシミュレーションが実行されるが，各属性の人員数 に応じたこれらの区分を“家庭タイプ”として定義した. 例えば，父1母1子2幼児1で構成される世帯はtype1121 と して区分した.

地域へ拡張したシミュレーションの実行に際して，対 象地域の自治体に実施された統計データ（2011年度）に 基づき家庭タイプごとの世帯数を推定した。推定した世 帯数分だけその家庭タイプ別のシミュレーションを行い, それらの和をとることで対象地域における感染者数とし た。また，ある家庭から異なる家庭への感染の拡大はな いものと仮定した.

\section{(3) 対象地域と微生物, 疫学データについて}

モデル適用の対象地域は東北地方のA町とし, 対象病 原微生物はノロウイルス $(\mathrm{NV})$ とした.

また, 疫学データとしては, 対象地域内の医療機関で 収集されたNV患者のデータ (標本数 $=38$, 週あたりの患 者数, 調查期間は2012年11月1日から1年間)を利用した. 


\section{(4) 一次感染の感染経路と曝露評価}

\section{a) 感染経路}

一次感染は, NVの流行期が冬季であり環境水一の曝露 は小さいと考えられること, 対象のA町は二枚貝の主要 生産地であり,二枚貝はNVの主要な一次感染源として認 知されているのことといった理由から，二枚貝の生食に よる経路のみを一次感染の感染経路と仮定した.

\section{b) 曝露評価}

1 日あたりの一次感染曝露量は以下の式で算出した.

$$
D_{1}=C_{1} \times V_{1} \times F_{1}
$$

$D_{l}:$ 二枚貝からのNV摂取量 $[\mathrm{NV}$ copies/日]

$C_{l}:$ 二枚貝中のNV濃度 $[\mathrm{NV}$ copies $/ \mathrm{g}]$

$V_{l}: 1$ 流行期間中の一回あたりの二枚貝摂取量 $[\mathrm{g} /$ 回 $]$

$F_{1}: 1$ 日あたりの二枚貝摂取回数[回/日]

\section{(5) 二次感染の感染経路と曝露評価}

\section{a) 感染経路}

二次感染のモデル構築を行うに際して，（病原微生物 を含む糞便を排出する）感染者 $\mathrm{O}$ 糞便が，その糞便を 処理した人物 $\mathrm{O}^{\prime}$ の手に付着し, 被曝露者 $\mathrm{P} か ゙$ 経口摂取す るまでの感染経路を想定した. 感染者 $\mathrm{O}$ の属性が父・母・ 子のいずれかのときは，自分の粪便は自分で処理できる ので, 処理者 $\mathrm{O}^{\prime}$ は感染者 $\mathrm{O}$ と同一人物となる.一方, 感 染者Oの属性が幼児のときには, O’ はそれを処理した異 なる人物（父・母・子のいずれか）とした. 自分の糞便 からは感染しないとし, 感染者 $\mathrm{O}$ と被曝露者 $\mathrm{P}$ は常に異な る人物とした.

感染者, 処理者, 被曝露者の間での病原微生物の移動 の機会とそのときの微生物移動量の計算方法については, 移動aからgとして表-1に示した．移動aからgをもとに以 下の5経路での曝露シナリオに対して曝露評価を行った.

表-1. 感染者から被曝露者までの病原微生物の移動の種類とそのときの曝露量の決定式.

\begin{tabular}{|c|c|c|}
\hline 移動の種類 & 決定する式 & 係数の意味 \\
\hline $\begin{array}{l}\text { a.おむつからおむつ処理者への } \\
\text { 糞便移動量 }[\mathrm{g} / \text { 日] }\end{array}$ & $A_{d}(i)=V_{d} \times F_{d}(i)$ & 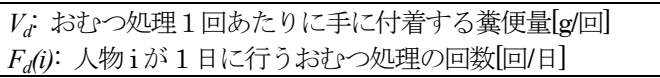 \\
\hline $\begin{array}{l}\text { b.糞便から排泄者自身の手への } \\
\text { 糞便移動量[g/日] }\end{array}$ & $A_{e}(i)=V_{e} \times F_{e}$ & $\begin{array}{l}V_{e}: \text { 排便処理 } 1 \text { 回あたりに手に付着する糞便量[g/回] } \\
F_{e}: 1 \text { 日あたりの下痢頻度[回/日] }\end{array}$ \\
\hline $\begin{array}{l}\text { c.人物 } \mathrm{i} \text { の手から人物 } \mathrm{j} \text { の手への } \\
\text { 糞便移動割合[-] }\end{array}$ & $T_{h h}(i)=t_{h h} \times f_{h h}(i-j)$ & $\begin{array}{l}t_{h h}: \text { 接触 } 1 \text { 回あたり手-手間の微生物移動割合[1/回] } \\
f_{h h}(i-j): \text { 人物 } \mathrm{i} \text { と jの接触回数[回] }\end{array}$ \\
\hline $\begin{array}{l}\text { d.人物 } \mathrm{i} の \text { 手から食品への } \\
\text { 糞便移動割合[-] }\end{array}$ & $T_{h f}(i)=t_{h f} \times f_{h f}(i)$ & 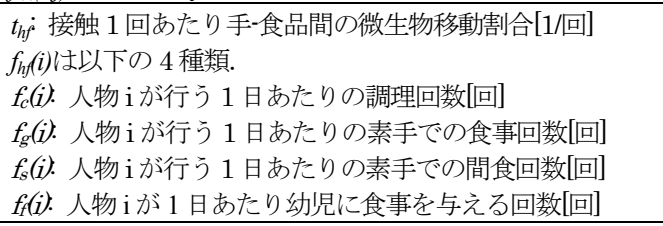 \\
\hline $\begin{array}{l}\text { e.食品から人物 } \mathrm{i} \text { の口への } \\
\text { 糞便移動割合[-] }\end{array}$ & $T_{f m}(i)=t_{f m} \times f_{f m}(i)$ & 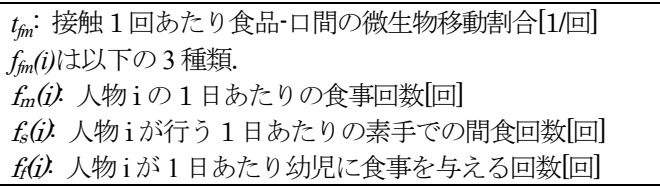 \\
\hline $\begin{array}{l}\text { f.人物 i の手から人物 i の口への } \\
\text { 糞便移動割合[-] }\end{array}$ & $\begin{array}{l}T_{h m}(i)=t_{h m} \times f_{h m}(i) \\
\text { ただし } f_{h m}(i)=m_{h m}(i) \times h_{h m}(i)\end{array}$ & $\begin{array}{l}t_{h m}: \text { 接触 } 1 \text { 回あたり手-口間の微生物移動割合[1/回] } \\
f_{h m}(f, m, c): \text { 成人の } 1 \text { 日あたりの口を触る頻度[回] } \\
f_{h m}(b): \text { 幼児の } 1 \text { 日あたりの口を触る頻度[回] } \\
m_{h m}(f, m, c): \text { 成人の } 1 \text { 時間あたりの口を触る頻度[回/時間] } \\
m_{h m}(b): \text { 幼児の } 1 \text { 時間あたりの口を触る頻度[回/時間] } \\
h_{h m}(f, m, c): \text { 成人の } 1 \text { 日あたりの行動時間[時間] } \\
h_{h m}(f, m, c): \text { 幼児の } 1 \text { 日あたりの行動時間[時間] }\end{array}$ \\
\hline $\begin{array}{l}\text { g.手洗浄による減少後の } \\
\text { 残存割合[-] }\end{array}$ & $\begin{array}{l}T_{w}(i)= \\
\left(t_{w w} \times p_{x w}(i)+t_{\text {ws }} \times p_{x s}(i)+t_{w n} \times p_{x n}(i)\right) \\
\times f_{w}(i)\end{array}$ & 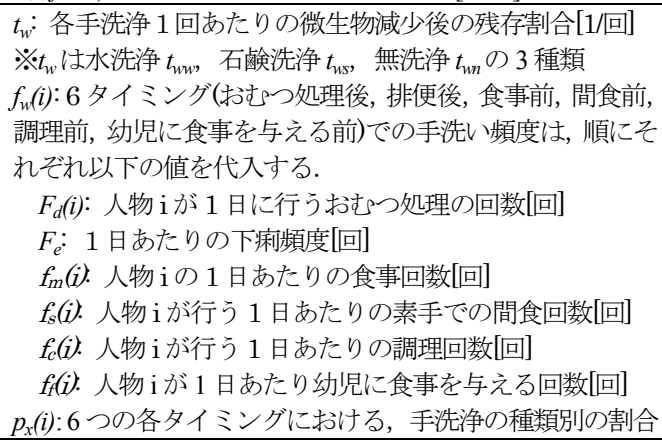 \\
\hline
\end{tabular}


経路1：感染者 $\mathrm{O}$ の資便処理者 $\mathrm{O} ’ か ゙$ 被曝露者 $\mathrm{P}$ に接触

し, 污染した手でが調理を行った食品を自身で摂取する

もしくは素手で食事を行うことで経口摂取する経路

経路 2 : 感染者 $\mathrm{O}$ の粪便処理者 $\mathrm{O} ’ か ゙$ 被曝露者 $\mathrm{l}$ に接触し, 污染した手でPが無意識に口を触り, 経口摂取する経路

経路 3 : 感染者 $\mathrm{O}$ の翼便処理者 $\mathrm{O}^{\prime}$ が調理を行い，その 食品を摂取することで経口感染する経路

経路4 : 感染者 $\mathrm{O}$ の凟便の処理を被曝露者 $\mathrm{P} か ゙$ 行い，污 染した手で訳調理を行った食品を自身で摂取するもし くは素手で食事を行うことで経口摂取する経路

経路5 : 感染者 $\mathrm{O}$ の粪便の処理を被曝露者 $\mathrm{P} か ゙$ 行い，污 染した手でPが無意識に口を触り, 経口摂取する経路

この5経路に，表-1のように6種類に分類したタイミン グの手洗いによる手に付着した微生物数の減少を考慮し て, 全属性・全経路の組み合わせについて計算を行った.

\section{b) 曝露評価}

上記の $5 つ$ 経路で 1 日当たりに曝露される病原微生 物量は, 以下の式で算出した.

$$
D_{2}=C_{2} \times A \times T
$$

$D_{2}:$ 感染者の粪便からのNV摂取量 $[\mathrm{NV}$ copies/日]

$C_{2}:$ 粪便中の $\mathrm{NV}$ 濃度 $[\mathrm{NV}$ copies $/ \mathrm{g}]$

$A:$ 糞便処理者 $\mathrm{O}^{\prime}$ の手につく糞便量 $[\mathrm{g} /$ 日]

$T:$ 微生物の移動割合[-]
ここで，Tは表-1のように算出を行なったが，例えば $\mathrm{T}_{\mathrm{hh}} \times \mathrm{T}_{\mathrm{hf}}$ のように一つの経路の中で複数種類のTを乗じ て計算を実行することに注意されたい.

\section{（6）パラメーターの決定に必要なデータ}

モデル構築に必要なパラメーターの決定のために, 既 存の実験・観測データの収集, および現地調查・アンケ 一ト調査を実行した，その詳細を表-2，表-4，表-5にま とめた. 本来, モンテカルロシミュレーションにおいて はパラメーターの分布型を加味することが望ましい.し かし，本研究で参考にした多くの文献データの分布型が 不明であることや，アンケート結果に信頼できる分布形 をあてはめるのが困難であったことから，本研究では平 均值での算出にとどめた.

また, 粪便中のNV濃度は不顕性感染の場合と顕性感染 の場合で異なることや，感染からの経過時間により異な ることが予想されるが，ここでは杉枝ら7のの調査結果の 最頻值である $10^{7}[\mathrm{NV}$ copies $/ \mathrm{g}]$ を代表值として用いた。 こ れは, Ozawa et al. ${ }^{8}$ の調査結果の算術平均値とも整合して いる. また， ウイルス排出期間については西尾ら ${ }^{9}$ が7〜 30 日間と報告していることから, まず最短の7日間を設定 し，その後30日間まで段階的に延長したケースでもシミ ユレーションを実行した.

表-2. 文献值によるパラメーター一覧.

\begin{tabular}{|c|c|c|c|c|}
\hline 項目 & 記号 & 数值 & 参考文献 & 備考 \\
\hline 糞便中 NV 濃度 [NV copies/g] & $C_{2}$ & $10^{7}$ & 杉枝ら，2004 & Ozawa et al. ${ }^{8)}$ と整合 \\
\hline ウイルス排出期間[日] & - & 7 & 西尾ら，2005) & - \\
\hline 病状継続期間 [日] & - & 考慮しない & - & - \\
\hline 免疫の獲得 [- ] & - & 考慮しない & - & - \\
\hline 不顕性確率 [-] & - & 考慮しない & - & - \\
\hline \multirow[t]{2}{*}{ Dose-response 式 } & \multirow[t]{2}{*}{-} & $P_{i n f}(d)=1-\left(1+\frac{d}{\beta}\right)^{-a}$ & \multirow[t]{2}{*}{ Teunis et al., $2008^{10)}$} & \multirow[t]{2}{*}{ 全員が Se+型と仮定 } \\
\hline & & $\alpha=0.631, \quad B=6.50 \times 10^{5}$ & & \\
\hline おむつから手 $[\mathrm{g}]$ & $V_{d}$ & 0.1 & Gibson et al., 2002 & - \\
\hline 成人の粪便から手 [g] & $V_{e}$ & 0.01 & 橋本, 2011 & - \\
\hline 手から口への微生物移動 [-] & $t_{h m}$ & 0.35 & Mark and Daniel. B, 2008 ${ }^{13)}$ & Influenza $A$ virus \\
\hline 手から手への微生物移動 [-] & $t_{h h}$ & 0.16 & Chen et al., 2011 & Enterobacter \\
\hline 手から食品一の微生物移動 [-] & $t_{h f}$ & 0.16 & Chen et al., 2011 ${ }^{14)}$ & Enterobacter \\
\hline 食べ物から口への移動[-] & $t_{f m}$ & 1 & - & - \\
\hline Triclosan 洗浄の残存割合 $[-]$ & $t_{W S}$ & 0.13 & Gibson et al., 2002 & E. coli \\
\hline 水洗浄の残存割合 $[-]$ & $t_{w w}$ & 0.32 & Bloomf ield et al., $2007^{15)}$ & E. coli \\
\hline 洗わない場合の残存割合 [-] & $t_{\mathrm{wn}}$ & 1 & - & - \\
\hline 下痢頻度 [回/日] & $F_{e}$ & 6.5 & Cheng et al., 20016) & Norovirus \\
\hline 口を触る頻度(成人) [回/時間] & $m_{h n}(f, m, c)$ & 8 & Mark and Daniel. B, 2008 & - \\
\hline 口を触る頻度 (幼児) [回/時間］ & $m_{h n t}(b)$ & 19 & Xue et al., $2007^{17)}$ & 3 ケ月から 6 歳の相加平均 \\
\hline 行動時間 (成人) [時間/日］ & $h_{h n l}(f, m, c)$ & 16 & $\mathrm{NIH}, 2011^{18)}$ & - \\
\hline 行動時間 (幼児) [時間/日］ & $h_{\text {han }}(b)$ & 8 & NIH, 2011 ${ }^{18)}$ & - \\
\hline 調理頻度(父) [回/日］ & $t_{h f}(f)$ & 0.16 & $※ 2$ & ※2 複数データ結合 ${ }^{19), 20)}$ \\
\hline 調理頻度 (母) [回/日］ & $t_{h t}(m)$ & 3 & $※ 3$ & ※3アンケート結果より \\
\hline 調理頻度(子) [回/日］ & $t_{h f}(c)$ & 0.31 & $※ 2$ & ※2 複数データ結合 \\
\hline 調理頻度 (幼児) [回/日］ & $t_{h f}(b)$ & 0 & - & - \\
\hline 食事の回数[回/日] & $f_{n}(f, m, c, b)$ & 3 & - & - \\
\hline
\end{tabular}




\section{(7) アンケート調査の方法}

対象地域の人々の行動習慣データを収集するため，ア ンケート調査を実施した．属性区分に従ったデータを収 集するため, 対象として世帯構成員数が 2 人以上の世帯を 想定し，単身世帯や二世帯住宅は対象から除外した．表 -4, 表-5に示した項目を含むアンケート票を作成し，対 象地域500世帯に対してポスティングを実施した. 500世 帯の選別方法は，対象地域をメッシュ状 $(770 \mathrm{~m} \times 500 \mathrm{~m})$ に10等分割し, 各メッシュ内からランダムに50世帯ずつ 抽出した. 回収率は $12.6 \%$ であった.

\section{(8) 二枚貝摂取に関する仮定}

上記のパラメーターに加え, (1)一次感染源となる食品 (二枚貝)を摂取する期間と(2)食品から摂取するNV量を 設定寸る必要がある.ここでは, 幼児を除く各属性が対 象の食品を摂取し，二枚貝のシーズン期間およびNV検查 の検出限界值からの推定に基づく值の設定を行った．こ の際，食品中に含まれる最高值(すなわち検出限界值)の NVを含んだ食品を摂食するものとして仮定した. その算
出した值および具体的な算出仮定を表-3にまとめた.

\section{3. 結果および考察}

\section{（1） アンケート結果およびパラメーターの決定}

アンケート結果は, 500世帯分配布し, 返送されたアン ケートが 62 世帯分, うち未記入などを除いたデータとし て有効なアンケートは58世帯分であった. アンケートの 結果を集計し，パラメーターとして利用する值を表-4, 表-5にまとめた.また, 他の研究者による実験データ等, 文献值にもとづいて決定したパラメーターについても前 頁の表-2にまとめた．これらのうち，一次感染および家 庭内二次感染のリスクに大きな影響を与える可能性があ るが不確定性の高いパラメーターとして, NVを含む食品 の摂取期間(1次曝露期間), 食品中のNV濃度(1次曝露量), $\mathrm{NV}$ 含む粪便の排出期間(2次曝露期間), 粪便中のNV濃 度(2次曝露量)を取り上げ, その流行拡大への影響につい てそれぞれ(3)で詳細に評価を行った。

表-3. 算出の際に必要な仮定

\begin{tabular}{|c|c|c|}
\hline 項目 & 数值 & 根拠 \\
\hline $\begin{array}{l}\text { 一次感染源となる食品の摂取 } \\
\text { 期間 }\end{array}$ & 120 [日] & 二枚貝のシーズンが 11-2 月の 4 ヶ月であることによる \\
\hline $\begin{array}{l}\text { 食品由来の } 1 \text { 人 } 1 \text { 日あたり } N V \\
\text { 摂取量 }\end{array}$ & $10^{2}[\mathrm{NV}$ copies/日 $]$ & $\begin{array}{l}1 \text { 人 } 1 \text { 日 } 1 \text { 個のカキを攝食, カキ } 1 \text { 個あたりの中腸腺重量 }{ }^{21} \text { は } 1[\mathrm{~g}] \text {, 中腸腺 } \\
\text { の NV 濃度を検出下限值である } 100[\mathrm{NV} \text { copies/g-中腸腺 }] \text { と仮定して (すなわ } \\
\text { 一日あたりの消費量を } 100[\mathrm{NV} \text { copies/日]と仮定し)それを } 1,14,30,120[\text { 日 }] \\
\text { 摂食する, というシナリオとして設定. }\end{array}$ \\
\hline
\end{tabular}

表-4. アンケート調查結果(接触頻度, 行動習慣).

\begin{tabular}{|c|c|c|c|c|}
\hline 項目 & 属性 & 分類 & 記号 & 数值 \\
\hline \multirow{7}{*}{$\begin{array}{l}\text { 手の接触頻度 } \\
\text { [回/日] }\end{array}$} & 父-母 & - & $f_{h h}(f, m)$ & 1.2 \\
\hline & 父-子 & - & $f_{h h}(f, c)$ & 2.6 \\
\hline & 父-幼児 & - & $f_{h h}(f, b)$ & 5.2 \\
\hline & 母-子 & - & $f_{h h}(m, c)$ & 5.9 \\
\hline & 母-幼児 & - & $f_{h h}(m, b)$ & 8.4 \\
\hline & 子-幼児 & - & $f_{h h}(c, b)$ & 6.5 \\
\hline & 子-子' & - & $f_{h h}\left(c, c^{\prime}\right)$ & 3.5 \\
\hline \multirow{8}{*}{$\begin{array}{l}\text { 手づかみ食事の頻度 } \\
\text { [回/日] }\end{array}$} & 父 & 食事 & $f_{g}(f)$ & 0.9 \\
\hline & & 間食 & $f_{s}(f)$ & 1.4 \\
\hline & 母 & 食事 & $f_{g}(m)$ & 1.0 \\
\hline & & 間食 & $f(m)$ & 1.7 \\
\hline & 子 & 食事 & $f_{g}(c)$ & 1.6 \\
\hline & & 間食 & $f_{s}(c)$ & 2.1 \\
\hline & 幼児 & 食事 & $f_{d}(b)$ & 0.0 \\
\hline & & 間食 & $f_{s}(b)$ & 0.0 \\
\hline \multirow{4}{*}{$\begin{array}{l}\text { おむむつ処理の頻度 [回/ } \\
\text { 日］ }\end{array}$} & 父 & - & $F_{d}(f)$ & 0.8 \\
\hline & 母 & - & $F_{d}(m)$ & 5.8 \\
\hline & 子 & - & $F_{d}(c)$ & 0.0 \\
\hline & 幼㠩 & - & $F_{d}(b)$ & 0.0 \\
\hline \multirow{4}{*}{$\begin{array}{l}\text { 幼児に食事を与える頻 } \\
\text { 度 } \\
\text { [回/日] }\end{array}$} & 父 & - & $f_{f}(f)$ & 1.0 \\
\hline & 母 & - & $f_{f}(m)$ & 3.0 \\
\hline & 子 & - & $f_{f}(c)$ & 0.0 \\
\hline & 幼巟 & - & $f_{f}(b)$ & 0.0 \\
\hline
\end{tabular}

(標本数 $\mathrm{N}=58)$

\begin{tabular}{|c|c|c|c|c|c|}
\hline $\begin{array}{l}\text { 属 } \\
\text { 性 }\end{array}$ & 分類 & 記号 & $\begin{array}{l}\text { し な } \\
\text { い[-] }\end{array}$ & $\begin{array}{l}\text { 水洗浄 } \\
{[-]}\end{array}$ & $\begin{array}{l}\text { 石 検 } \\
{[-]}\end{array}$ \\
\hline \multirow[t]{6}{*}{ 父 } & \multirow{6}{*}{$\begin{array}{l}\text { 排便後 } \\
\text { 食事前 } \\
\text { 間食前 } \\
\text { 調理前 } \\
\text { おむつ処理後 } \\
\text { 幼児に食事を } \\
\text { 与える前 }\end{array}$} & $p_{\text {en, ew, es }}(f)$ & 0.10 & 0.74 & 0.17 \\
\hline & & $p_{m n, n, m, ~ m s}(f)$ & 0.29 & 0.38 & 0.33 \\
\hline & & $p_{S n, \text { SW, SS }}(f)$ & 0.64 & 0.33 & 0.02 \\
\hline & & $p_{c n, c \text { w , cs }}(f)$ & 0.04 & 0.57 & 0.39 \\
\hline & & $p_{d r, d w, d s}(f)$ & 0.50 & 0.00 & 0.50 \\
\hline & & $p_{f n, f u, f s}(f)$ & 0.00 & 1.00 & 0.00 \\
\hline \multirow[t]{6}{*}{ 母 } & \multirow{6}{*}{$\begin{array}{l}\text { 排便後 } \\
\text { 食事前 } \\
\text { 間食前 } \\
\text { 調理前 } \\
\text { おむつ処理後 } \\
\text { 幼児に食事を } \\
\text { 与える前 }\end{array}$} & $p_{\text {en, ew, es }}(m)$ & 0.00 & 0.60 & 0.40 \\
\hline & & $p_{m m, n w, m s}(m)$ & 0.13 & 0.51 & 0.36 \\
\hline & & $p_{S n, S W, S S}(m)$ & 0.38 & 0.45 & 0.17 \\
\hline & & $p_{c n, c W, c s}(m)$ & 0.02 & 0.38 & 0.60 \\
\hline & & $p_{d n, d w, d s}(m)$ & 0.00 & 0.40 & 0.60 \\
\hline & & $p_{f n, f w, f s}(m)$ & 0.00 & 1.00 & 0.00 \\
\hline \multirow[t]{6}{*}{ 子 } & \multirow{6}{*}{$\begin{array}{l}\text { 排便後 } \\
\text { 食事前 } \\
\text { 間食前 } \\
\text { 調理前 } \\
\text { おむつ処理後 } \\
\text { 幼児に食事を } \\
\text { 与える前 }\end{array}$} & $p_{\text {en, ew, es }}(c)$ & 0.00 & 0.71 & 0.29 \\
\hline & & $p_{m z, n W, m s}(c)$ & 0.13 & 0.38 & 0.50 \\
\hline & & $p_{S n, S W, S S}(c)$ & 0.50 & 0.29 & 0.21 \\
\hline & & $p_{C n, C H, C S}(c)$ & 0.00 & 0.33 & 0.67 \\
\hline & & - & - & - & - \\
\hline & & - & - & - & - \\
\hline
\end{tabular}




\section{(2) 対象地域におけるシミュレーション結果}

図-1より, シミュレーション結果の 1 日あたり感 染者数が一人以下となる日があった。これは，モン テカルロ法を用いて, 各家庭タイプ別に 10,000 世帯 分シミュレーションを行った結果を対象地域の世帯 数分に換算しているためである.

1 日あたり感染者数は, 1 次曝露期間の 120 日目ま で振動しながら増加し続け, その後単調減少に転じ た.これは, 1 次曝露期間中は一定量の 1 次曝露を 受けることに加え, 感染者由来の 2 次曝露も受ける ことに起因しているものと考察できる.

また，図-1 のとおり，365 日後 (1 年後)まで感染 者数が 0 にならない.この図に示した感染者数は, 複数種類の家庭タイプにおける試行の結果を各タイ プの世帯数分合算した期待值であり, 0 以上 1 未満 となる場合もあった，以降の考察では，この期待值 が 1 未満である場合には, 感染拡大が終息したもの と判断した.
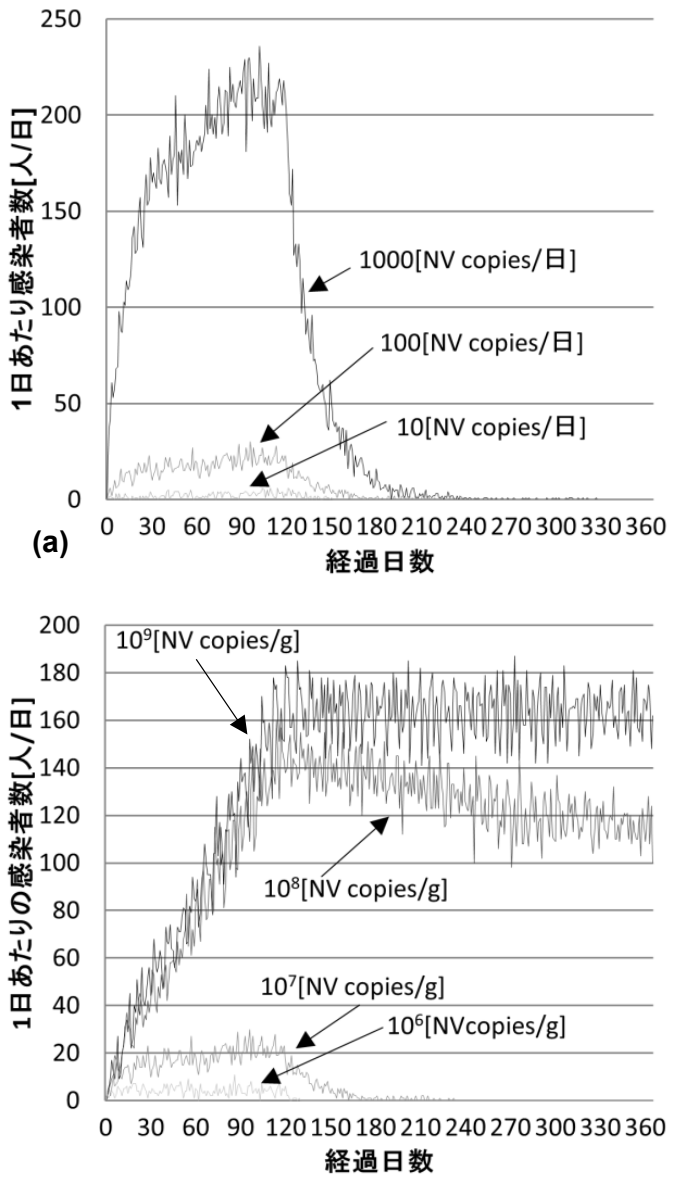

(c)

図-2. 父 1 母 1 子 1 幼児 1 の 4 人世帯が 10,000 世帯 (人口 40,000 人)存在する都市を仮想した場合の算出結果. ここで, 左上 (a) は 1 日あたりの食品由来 NV 摂取量 (1 次曝露量)，右上 (b) は NV を含む食品を摂取する期間 (1 次曝露期間)，左下 (c) は粪便中の NV 濃度 (2 次曝露量)，右下 (d) は NV を含む粪便の排出期間 (2 次曝露期間)を示している. 
メーター以外の值は表-2, 表-3の值に固定してシミュレ ーションを行った.

シミュレーションの結果は，1日当たりの感染者数が 最大值をとる時点をピーク, 感染者数が1未満, すなわち 0で定常状態になっている始まりの時点を終息とすると, 表-6のようになった. ここで, 本シミュレーションでは 単一の家庭タイプから算出したため, 結果は整数值とな り，1未満の数は全て0となった. それぞれのパラメータ 一の影響は，以下の通りであった。

\section{a) 1次曝露量を変化させた場合}

ピークまでの所要時間は変わらず，終息までの所要時 間は食品中NV濃度が高い順に大きくなった. ピークの位 置が変わらない原因は, どのNV濃度の場合も二次感染経 路および2次曝露量が最も多くなる時点が120日目(1次曝 露期間終了日)付近に位置することによるものと考察で きる. 一方, 食品中NV濃度の増加に伴い, 終息までの所 要時間が増加する理由は, ピーク時点での1日あたり感染 者数が大きいためだと考えられる. ピーク以降, 各家庭 での感染者数の増減は家庭内に存在する感染者数に応じ た確率で起こる．家庭あたりの感染者数が増加すれば家 庭内二次感染を起こす確率が高くなる，家庭あたりの感 染者数が増加しない場合には, 感染者のいる家庭数が増 加する. その場合, 確率が等しいために, 前日の感染者 の存在する家庭数が多いほど, その翌日の感染者の存在 する家庭数は増える. したがって，ピーク時点の感染者 数が多いほど, その翌日以降の感染者数の期待值は大き くなり, 終息までの所要時間は増加するものと考えられ る.

\section{b) 1 次曝露期間を変化させた場合}

ピークまでの所要時間, ピークから終息までの所要時 間はともに増加した。

1次曝露期間中は一定量の1次曝露を受けることに加え, 感染者由来の 2 次曝露も受けるために, 感染者が増えるほ ぞ感染リスク (一次感染または二次感染する確率) は高ま る. したがって, 1次曝露期間の終了日にピークが来る結 果となり, ピークまでの所要時間は1次曝露期間に依存す ると考えられる．また，ピークから終息までの所要時間 については曝露期間が長いほど，ピーク時の感染者数が 多くなる結果となった．これは前項で述べた，ピーク時 における感染者数の増加に起因しているものと考察でき る.

\section{c) 2次曝露量を変化させた場合}

ピークまでの所要時間は変わらず, 終息までの所要時 間は粪便中 NV 濃度が高い順に大きい結果となった.

ピークまでの所要時間への影響要因については, a) と同 じ要因が想定される．また，ピークから終息までの所要 時間については，a)および b)での傾向とほぼ同じであっ たが $10^{9}[\mathrm{NV}$ copies/g]の感染者数がピークから減少しな
い結果が得られた。これは，粪便中 NV 濃度が高くなる 場合, 1 日あたりの NV 摂取量が増加し，1 に限りなく近 い確率で家庭内二次感染を引き起こすことに起因してい ると考えられる. 感染者数が全く減少しない結果は現実 に反しているが，一方で 2 次曝露量が大きい場合には 1 年間を超えて 2 次感染者が残存する可能性があるといえ る. このことを考慮すると, 初期の感染者がいない仮定 で行った今回のシミュレーションとは異なる結果が得ら れるであろう。

\section{d) 2次曝露期間を変化させた場合}

ピークまでの所要時間は変わらず, 終息までの所要時 間はNVを含む糞便の排出期間が長い順に大きい結果と なった. ピークまでの所要時間への影響要因については, a) と同じ要因が想定される．ピークから終息までの所要 時間の増加要因は, NVを含む粪便の排出期間が長くなる ほど, 感染者 1 人が新たな感染者を発生させる確率が高ま ることによるものと考察できる. c) と同様に，2次曝露期 間が長いと想定される場合にも, 前年度から2次感染者が 残存者数を加味したシミュレーションが必要となる.

\section{(4) 家庭タイプ別の比較}

前述した4つのパラメーターの他に, 家庭タイプが流行 を左右する重要な要因である. 家庭内で少なくとも一人 二次感染するリスクと家庭内で少なくとも一人一次感染 するリスクの比を取ることで, 家庭タイプ別に二次感染 リスクの比較を行った（これをリスク比と定義する．) 一般に, 人員が多いほど一次感染リスク, 家庭内二次感 染リスクは共に増加すると考えられるが，このリスク比 を用いることで，一次感染リスクを基準とした家庭内二 次感染リスクの大きさを評価できる.次頁図-3を見ると, 母子家庭 (type.1010) などを除き, 多くの家庭タイプで 家庭内二次感染リスクが一次感染リスクよりも大きい結 果となった. 構成員数の多い家庭, 特に幼児が多く存在 する家庭ほどリスク比は大きい結果となった．中でも総 員4人以上でかつ幼児が存在する家庭は, リスク比が 10 以上となった. これには，幼児のおむつ処理，子供の接 触が感染拡大に大きく寄与していると考えられる.また, 幼児は二枚貝からの感染がない, 寸なわち一次感染リス クが0であることも, 幼児が存在する家庭のリスク比を増 加させる要因になっていると考えられる.

\begin{tabular}{|c|c|c|c|c|}
\hline & $\begin{array}{c}\text { 1次 } \\
\text { 曝露量 }\end{array}$ & $\begin{array}{c}\text { 1次 } \\
\text { 曝露期間 }\end{array}$ & $\begin{array}{c}\text { 2次 } \\
\text { 曝露量 }\end{array}$ & $\begin{array}{c}\text { 2次 } \\
\text { 曝露期間 }\end{array}$ \\
\hline $\begin{array}{c}\text { 開始から } \\
\text { ピーク }\end{array}$ & 変化なし & 増加 & 変化なし & 変化なし \\
\hline $\begin{array}{c}\text { ピーク } \\
\text { から収束 }\end{array}$ & 増加 & 増加 & 増加 & 増加 \\
\hline
\end{tabular}




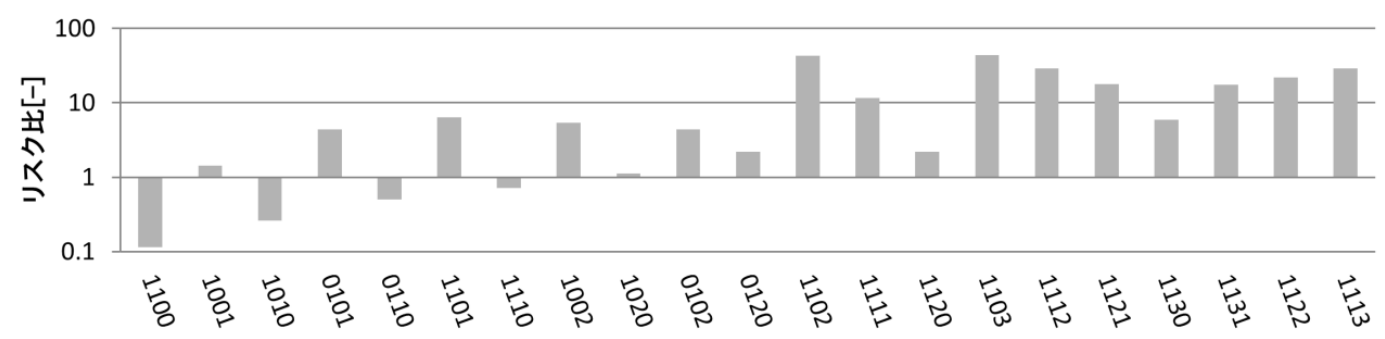

家庭タイプ

図-3. 家庭タイプ別のリスク比の比較. ここでリスク比は, ”少なくとも 1 人家庭内二次感染するリスク”と”家庭内で少なくと も 1 人一次感染するリスク”の比を表している. また，家庭タイプは，例えば type. 1113 であれば父 1 母 1 子 1 幼児 3 を表して いる.
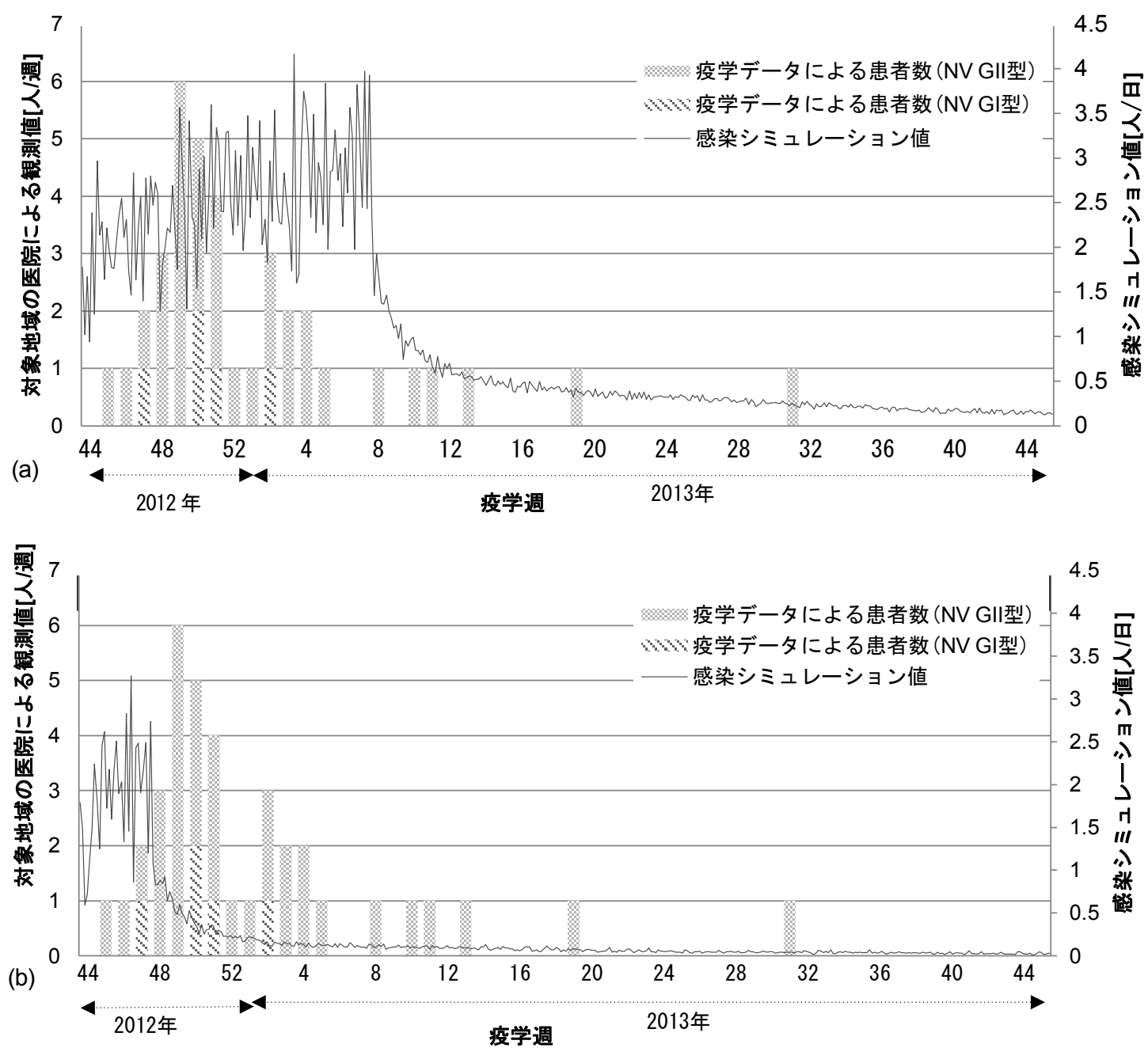

図-4. 対象地域におけるシミュレーションによる 1 日あたりの感染者数と, 疫学データによる週あたり感染者数の推移の比較. ここで，図上(a)は 1 次曝露期間を 120 日にしたシミュレーション值と疫学データの比較，図下(b) は 1 次曝露期間を 30 日にし たシミュレーション值と疫学データの比較を表している.

\section{(5) 対象地域におけるシミュレーション結果と疫学デ} 一タの比較

(2)で算出した対象地域でのシミュレーション結果を 対象地域内の医療機関で収集された疫学データと図-4の ように比較した．図-4（a）に対象地域の感染者シミュレ ーション值を折れ線グラフで, 疫学データを棒グラフで 示した. なお，このシミュレーションには，家庭一家庭 間の感染や不顕性感染, 血液型抗原の非分泌型（Se-型） 
の住民の存在が考慮されていないため, 感染者の絶対数 を正確に定量しているとは言いがたい，同様に，疫学デ 一夕も, 対象地域のある病院からのノロウイルス胃腸炎 の患者の報告にもとづいているため, 症状のある感染者 の一部を捉えているに過ぎない. このことから, この図 で感染者の絶対数を比較することには意味がない. 感染 開始からピークまでの所要時間を比較すると, 図-4(a) および図-4(b) から実際の感染流行が示す所要時間は, 1 次曝露期間を 120 日および30日に設定したシミュレーシ ヨン結果での所要時間の間にあった。 また, 本シミュレ ーションで具体的にピーク時期を一致させることができ なかったのは, モンテカルロ法により算出された感染者 数が上下し, 算出されるピーク時期が一定しなかったた めである. このピーク時期についても, 本モデルに加味 されていない家庭-家庭間の感染や, シミュレーション開 始時に存在する前年度からの感染者の存在など, 1 次曝露 期間以外の条件によってもピーク時期は左右される可能 性がある.

しかし，今後これらの様々なパラメーターを精査した 上で, 1 次曝露期間を変更して疫学データとの比較検証を 行うことができれば, 本モデルは1次曝露期間の推定に対 して有用なツールになるものと考えられる.

本研究では，二枚貝のウイルス濃度やそれを摂食する 期間, 感染者の糞便のウイルス濃度とその排出期間など のパラメーターに着目して, 家庭での二次感染を考慮し て地域内での感染流行のシミュレーションを行った。こ れらは, 原因食品のもともとの污染や, 人間の体内での ウイルスの挙動に関するパラメーターであり, 地域住民 が日常生活の中で対策することはできない，一方で，手 洗いの頻度や接触頻度については, 個々人で対策が可能 であり，モデルの手洗いや接触頻度などの各行為に関す るパラメーター(表-4のfや表-5のpなど)を変化させるこ とにより，その効果を算定することができるであろう. 二枚貝の污染を低減するような対策だけでなく，住民の 衛生意識の向上のようなソフトな対策により，ノロウイ ルス胃腸炎の流行をどれだけ食い止めることができるの か，は行政にとって価值のある情報である．この種の情 報を提供できることが本モデルの利点であり，今後期待 されるモデルの利用方法である.

\section{4. 結論}

本研究では, 第1に, 家庭内二次感染を考慮した家庭内 伝播モデルを構築した. 第2に, 地域内の全世帯に対して 家庭内伝播モデルを実行することで地域内の感染流行シ ミュレーションを行なった. 第3に, 対象地域におけるシ ミュレーション結果と疫学データを比較することで本モ デルの有用性を示した.
その後, 不確定性の高い4つのパラメーターの影響感度 を検証し，ピークまでの所要時間は，4つの中では1次曝 露期間(NVを含む食品の摂取期間)にのみ敏感に反応寸 ることがわかった．また，家族構成別に一次感染リスク と家庭内二次感染リスクを比較することで，ほとんどの 家庭で一次感染リスクよりも家庭内二次感染リスクが大 きいことを定量的に示した. 特に, 幼児や子供といった 属性が存在する家庭構成であれば家庭内二次感染リスク が大きくなることを，リスク比を用いて示した. 幼児が 存在する4人以上の家庭では家庭内二次感染リスクは一 次感染の10倍以上になった. 最後に，上記の考察を利用 し, 対象地域におけるシミュレーションと疫学データと の比較を通じて, 本シミュレーションが実際の流行にお ける1次曝露期間を推定する有用なツールとなり得るこ とを示した.

今後の課題として, 家庭内伝播モデルの完成度の向上 のために，モノを介する感染や飛沫感染，嘔吐による感 染拡大などといった経路を組み込むことが必要となる. これらの感染経路が反映されると, 粪口経路のみを考慮 した本研究でのシミュレーション結果に比べて, 感染が より大規模に拡大していくものと考えられる.

また，それを地域内伝播モデルに拡張する際に，家庭 一家庭間の感染，家庭外でのヒト-ヒト感染もモデルに組 み込む必要がある. 最後に, パラメーター值の信頼度の 向上が望まれる，具体的には，NVの糞便中濃度やNVを 含む賈便の排出期間などに関する知見, 分布型を考慮し たデータの集積である．それらを加味することができれ ば, 本モデルの予測精度および有用性が高まり, ソフト, ハードの両面で種々の対応を講じた場合の効果について, 精緻な定量的評価が可能となるであるう.

謝辞 : 本論文は, 科学技術振興機構による戦略的創造研 究推進事業研究 (CREST) の「迅速・高精度・網羅的な病原 微生物検出による水監視システムの開発」の研究成果で ある. なお, 対象地域の疫学データは東北大学大学院医 学系研究科押谷仁教授よりご提供賜った. ここに記して 感謝の意を表する.

\section{参考文献}

1) WHO: Water, Sanitation and Hygiene Links to Health, FACTS AND FIGURES, 2004.

2) 重茂浩美 : ノロウイルスによる食中毒・感染症一我が国に おける発生状況とその対策について一, 科学技術動向, No.88, 2008.

3) Mamadou B.C. Diallo, Alfredo J. Anceno, Benjawan Tawatsupa, Eric R. Houptb, Voranuch Wangsuphachart and Oleg V. Shipin: Infection risk assessment of diarrhea-related pathogens in a tropical canal network, Science of the Total Environment, Vol.407, pp.223-232, 2008.

4) J.A.E. ten Veldhuis, F.H.L.R. Clemens, G. Sterk and B.R. Ber- 
ends: Microbial risks associated with exposure to pathogens in contaminated urban flood water, Water Research, Vol.44, pp.2910-2918, 2010.

5) Haas, C.N., Rose, J.B. and Gerba, C.P.: Quantitative Microbial Risk Assessment, John Wiley \& Sons, Inc, 1998.

6) European Food Safety Authority: Scientific Opinion on Norovirus (NoV) in oysters: methods, limits and control options, EFSA Journal, Vol.10, pp2500, 2012.

7) 杉枝正明, 新川奈緒美, 大瀬戸光明, 徳竹由美, 山口卓, 秋 山美穂, 西尾治 : Norovirus 感染により排泄されるウイルス 量について, 臨床とウイルス, Vol.32, No.3, pp.189-194, 2004.

8) Kazuhiro Ozawa, Tomoichiro Oka, Naokazu Takeda and Grant S. Hansman: Norovirus Infections in Symptomatic and Asymptomatic Food Handlers in Japan, Journal of Clinical Microbiology, Vol.45, pp3996-pp4005, 2007

9) 西尾治, 秋山美穂, 愛木智香子, 杉枝正明, 福田伸治, 西田 知子, 植木洋, 入谷展弘, 篠原美千代, 木村博一 : ノロウイ ルスによる食中毒について，食衛誌，Vol.46，No.6, pp.235-245, 2005.

10) Peter F.M. Teunis, Christine L. Moe, Pengbo Liu, Sara E. Miller, Lisa Lindesmith, Ralph S. Baric, Jacques Le Pendu and Rebecca L. Calderon: Norwalk Virus: How Infectious is It? Journal of Medical Virology, Vol.80, pp.1468-1476, 2008.

11) L.L. Gibson, J.B. Rose, C.N. Haas, C.P. Gerba and P.A. Rusin: Quantitative assessment of risk reduction from hand washing with antibacterial soaps, Journal of Applied Microbiology Symposium Supplement, Vol.92, pp.136-140, 2002.

12）橋本佳奈: 定量的リスク評価手法を用いた洪水を原因 とする水系感染症の数理モデル構築, 東京大学大学院 工学系研究科修士論文, 2011
13) Mark Nicas and Daniel Best: A Study Quantifying the Hand-to-Face Contact Rate and Its Potential Application to Predicting Respiratory Tract Infection, Journal of Occupational and Environmental Hygiene, Vol.5, pp.347-352, 2008.

14) Yuhuan Chen, Kristin M. Jackson, Fabiola P. Chea and Donald W. Schaffner: Quantification and Variability Analysis of Bacterial Cross-Contamination Rates in Common Food Service Tasks, Journal of Food Protection, Vol.64, No.1, pp.72-80, 2001.

15) Bloomfield and Sally F.: Preventing infectious disease in the domestic setting: a risk-based approach, American Journal of Infection Control, Vol.29, pp.207-212, 2001.

16) Wei-xia Cheng, Xin-hua Ye, Xue-mei Yang, Yu-ning Li, Miao Jin, Yu Jin and Zhao-jun Duan: Epidemiological study of human calicivirus infection in children with gastroenteritis in Lanzhou from 2001 to 2007, Arch Virol, Vol.155, pp.553-555, 2010.

17) Jianping Xue, Valerie Zartarian, Jacqueline Moya, Natalie Freeman, Paloma Beamer, Kathy Black, Nicolle Tulve and Stuart Shalat: A Meta-Analysis of Children's Hand-to-Mouth Frequency Data for Estimating Non dietary Ingestion Exposure, Risk Analysis, Vol.27, No.2, pp.411-420, 2007

18) US-NIH: Your guide to healthy sleep "How much sleep is enough?", pp.19-21, 2011.

19) 内閣府食生推進室 : 親子のための食育読本, pp.41-44,2010.

20）日清オイリオ生活科学研究室: 生活科学情報ショートレポ 一ト no.13,pp.2, 2009.

21）広島県保健環境センター: 平成 15 年度赤潮・貝毒等被害 防止対策事業(貝毒対策)報告書, pp.3, 2004

(2014. 5. 23 受付)

\title{
DEVELOPMENT OF TRANSMISSION MODEL FOR NOROVIRUS GASTROENTELITIS CONSIDERING SECONDARY INFECTION IN HOUSEHOLD
}

\author{
Fuminari MIURA, Toru WATANABE, Kozo WATANABE, Kensuke FUKUSHI
}

To predict transmission pattern of Norovirus gastroenteritis at regional scale, we've constructed an infectious disease transmission model that considers secondary infection in households. In the model, a household-scale submodel that could simulate secondary infection within family members was independently and in parallel applied to all households in the modeled region. The result of simulation showed that the effect of the secondary infection on the spread of the Norovirus gastroenteritis was larger than the primary infection. In particular, households of more than four family members including infant(s) showed ten times higher infectious risk of the secondary infection. Based on comparisons with empirical epidemiological data in the modeled region, our approach demonstrated a high utility of the model in estimating the exposure time from the primary infection time. 